\title{
NATURAL RESISTANGE OF BAMBUSA VULGARIS TO TERMITE AND POWDER-POST BEETLE ATTACK
}

\author{
Sadiku NA ${ }^{1}$, Bada OS ${ }^{1}$, Oluyege $\mathrm{AO}^{2} \&$ Ajayi $\mathrm{B}^{2}$ \\ ${ }^{1}$ Department of Forest Resources Management, University of Ilorin, 240003 Nigeria \\ ${ }^{2}$ Department of Forestry and Wood Technology, Federal University of Technology, Akure, 340252 Nigeria \\ *sadiku.na@unilorin.edu.ng
}

Submitted March 2020; accepted February 2021

\begin{abstract}
Deterioration is the major setback to the utilisation of bamboo products. To enhance bamboo utilisation, an understanding of the level of resistance to degradation is important. In this study, natural resistance of Bambusa vulgaris to attack by termites and powder-post beetle were evaluated. Bamboo aged 2, 3 and 4 years old were subjected to attack by subterranean termites and powder-post beetles for six month in a short span field tests. After exposure to attack by selected degrading insects, the weight loss was determined. There was significant variation in termite resistance among the three age classes, while no variation occurred along the culm length. In contrast to termite resistivity, resistance to powder-post beetles infestation varied significantly along the culm length from base to the top, while resistance among the three age classes were similar. Age 4 exhibited highest resistance to termites and were therefore placed in 'resistant' class, while age 3 , basal and middle portion were moderately resistant. The resistance of $B$. vulgaris from all the age classes and culm portion against powder-post attack was poor. The findings showed that termite resistance depend on culm age while that of powder-post is indifferent to age or the culm portion.
\end{abstract}

Keywords: Bamboo, culm age, culm portion, chemical content, biodegradation, resistivity

\section{INTRODUCTION}

Bamboo in general is not durable. There are many different types of degrading agents which infest and deteriorate bamboo under different environment conditions, and produce various visible changes on bamboo products (Aminudin et al. 2018). It is believed that durability of bamboo is a function of its density. However, bamboo's natural durability to resist biological attack does not correspond to its density (Das \& Chakraborty 2006). According to several reports, durability strongly depend on the species, the length of the culm, thickness of the wall as well as the time of harvest (Dhawan and Mishra 2005, Razak et al. 2010, Suprapti et al. 2010, Schmidt et al. 2011, Wei et al. 2013). However, Abd. Latif et al. (1991) and Chavan and Attar (2013) comfirmed that, the durability of bamboo against mould, fungal and borers attack is strongly associated with the chemical composition. The carbohydrate content of bamboo plays an important role in its durability and service life. Bamboo does not possess toxic extractives to impart natural durability, unlike the heartwood of many durable timbers, thereby making it highly prone to attack by biological organisms
(Huang et al. 2014). Without preservation, bamboo becomes susceptible to attack by mould and fungi, especially Aspergillus spp., Penicillium spp. and Trichoderma spp., resulting in degraded performances, shortened service life and reduced value (Pasanen et al. 2000, Nielsen et al. 2004). The graveyard test conducted by Kumar et al. (1994) have shown that the average life of untreated bamboos is less than two years, precisely between 1-36 months. However, Xu et al. (2013) showed that untreated bamboo has a service life of only $2-5$ years. Previous study by Kim et al. (2011) confirms that the natural durability of bamboo in outdoor utilisation is low. Approximately $40 \%$ of bamboo stack may be lost within a period of 8-10 months due to borer attack (Thapa et al. 1992).

Most Asian countries have embarked on research as well as product development from bamboo. However, bamboo research is still in its infancy in Nigeria, although demonstrations have been made on utilisation of bamboo for glue laminated products and particle boards (Ogunsanwo and Terziev 2010, Olajide et al. 2013, Ogunsanwo et al. 2015). These products were 
made with little documented information on the natural resistance of bamboo to deterioration. Like wood, ageing of bamboo culm influences its properties and consequently its processing and utilisation (Sadiku and Bada 2017, Chauhan et al. 2000). Deterioration is the major setback to the utilisation of bamboo products. In processing and utilising bamboo, an understanding of the level of resistance to degradation is important as it affects its service life. In the present study, the level at which Bambusa vulgaris, from natural stands and different ages, will repel attack from subterranean termites and powder-post bettel in its natural state was examined. The findings are important for effective bamboo preservation against biodegradating agents.

\section{MATERIALS AND METHODS}

\section{Selection and preparation of samples}

Culms aged 2, 3 and 4 years old were harvested from bamboo grooves growing naturally on the campus of Federal University of Technology, Akure, Nigeria. Three culms from each age class were harvested. The culms were carefully marked and labelled according to ages, and from base to the top portion along the culm length, for easy identification

Experimental specimens were sampled at 10,50 and $90 \%$ of the merchantable height to represent the base, middle and top positions of the bamboo culm. The samples were obtained from clear and uniform grained culms that contained no obvious flaws such as splits, checks and cross grains. The samples for chemical properties analysis were milled in their fresh state to pass BS 40-mesh sieve (425 $\mathrm{mm})$, and retained on $\mathrm{BS} 60$-mesh (250 $\mathrm{mm}$ sieve). They were later shade dried until constant moisture content was attained. Bamboo density was determined according to ASTM D 2395-93 (ASTM 1993), alcohol-benzene solubility according to TAPPI standard T204 cm-97, hot and cold water solubility according to TAPPI standard T207 cm-99, N/10-NaOH solubility according to TAPPI standard T212 cm-02, holocellulose content according to TAPPI standard T249 cm-85 and the $\alpha$-cellulose content according to TAPPI standard T203 cm-99 (TAPPI 1985, 1997, 1999, 2002). Hemicelluloses content was determined by the difference of Holocellulose and Cellulose content. Klason lignin content was determined according to TAPPI Standard T222 cm-06 method (TAPPI 2006).

\section{Termite and powder-post durability assays}

Bamboo samples measuring $20 \times 20 \times 20 \mathrm{~mm}$ and $20 \times 20 \times 375 \mathrm{~mm}$ were cut from the base, middle and top portions of 2, 3 and 4 years old B. vulgaris culms for termite and powder-post beetle resistivity tests. For each of the resistance test, the test samples were first dried to constant weight to obtain the initial weight before treatment. The bamboo samples were then exposed to subterranean termites and powderpost beetle for a duration of 3 and 6 month, respectively, following AWPA Standard E-21 (2006). Termite bioassay was experimented in a timber graveyard while powder-post bioassay was conducted in the laboratory. Visual observations were made weekly. At the end of the exposure period, weight loss due to termite and beetle infestation were determined gravimetrically following Indonesian National Standard, SNI 01.7207-2006 (SNI 2006). Each specimen was examined and visually rated as specified in AWPA (2009) Standard E1-09 (Table 1).

Each of the bamboo specimens were dried to constant weight before exposure to the biological agents. After the exposure period, adhering soil on the termite infested samples and residual powder on powder-post infested samples were removed. The specimens were then dried at $60{ }^{\circ} \mathrm{C}$ to constant weight. Weight losses were determined by comparing with pre-exposed values. The average percentage weight loss is indicated by resistance classes to specific test organism which ranged from resistant to slightly resistant or non-resistant (Table $3 \& 4$ ).

$$
\begin{aligned}
\text { Weight loss }(\%)= & \text { Initial weight }- \text { final weight } / \\
& \text { Initial weight } \times 100
\end{aligned}
$$

where initial weight is the weight before exposure and final weight is the weight after exposure.

\section{Statistical analysis}

Analysis of variance was used to evaluate the effect of age on bamboo properties at $\mathrm{p} \leq 0.05$. Mean separation for the different age classes was carried out using Duncan Multiple Range Test (DMRT). Correlation analysis was used to determine the relationship between the culm 
Table 1 Rating system for visual examination of termite and powder-post damage in bamboo specimens using the scale described in AWPA Standard E1-09 (2009)

\begin{tabular}{cl}
\hline Rating & Severity of attack \\
\hline 10 & Sound \\
9.5 & Trace, surface nibbles permitted \\
9 & Slight attack up to $3 \%$ of cross sectional area affected \\
8 & Moderate attack, 3-10\% of cross sectional area affected \\
7 & Moderate/severe attack, penetration, 10-30\% of cross sectional area affected \\
6 & Severe attack, 30-50\% of cross sectional area affected \\
4 & Very severe attack, 50-70\% of cross sectional area affected \\
0 & Failure \\
\hline
\end{tabular}

Table 2 Classification of resistance to termite attack based on SNI 01.7202.2006 rating

\begin{tabular}{ccc}
\hline Natural durability class & Weight loss $(\%)$ & Class of Resistance \\
\hline I & $<3.52$ & Very resistant \\
II & $3.52-7.50$ & Resistant \\
III & $7.50-10.96$ & Moderate \\
IV & $10.96-18.94$ & Poor \\
V & $18.94-31.89$ & Very poor \\
\hline
\end{tabular}

Table 3 Classification of resistance to powder-post attack based on SNI 01.7202.2006 rating

\begin{tabular}{ccc}
\hline Natural durability class & Weight loss $(\%)$ & Class of resistance \\
\hline I & $<2.0$ & Very resistant \\
II & $2.0-4.4$ & Resistant \\
III & $4.4-8.3$ & Moderate \\
IV & $8.3-28.1$ & Poor \\
V & $>28.1$ & Very poor \\
\hline
\end{tabular}

properties and the natural durability of the bamboo against deterioration.

\section{RESULTS AND DISCUSSION}

\section{Density and chemical properties of Bambusa vulgaris}

The culm density and chemical properties of B. vulgaris aged 2, 3 and 4 years are shown in Table 3. The highest and lowest culm density was recorded for top portion of age 3 and basal portion of age 2 respectively. Cellulose and lignin content were highest at top portion of age 2 and lowest at the basal portion of age 3 , while alcoholbenzene solubility was highest at top portion of age 4 and lowest at middle portion of 2 year old bamboo (Table 3 ).

\section{Resistance to termite and powder-post Beetles}

The findings of this work showed that resistance of $B$. vulgaris to termite attack varied significantly with culm age while no significant variation existed along the culm length. However, statistical differences occurred in the resistance to powderpost beetle along the culm length in contrast to termite resistivity. The interaction of age and culm portion on bamboo durability were however not significant for both wood destroying insects (Table 5). It was observed that the outer layer 
Table 4 Density and chemical properties of Bambusa vulgaris

\begin{tabular}{lcccccc}
\hline \multirow{2}{*}{ Properties } & \multicolumn{3}{c}{ Age (years) } & \multicolumn{3}{c}{ Portion } \\
\cline { 2 - 7 } & 2 & 3 & 4 & Base & Middle & Top \\
\hline Density $\left(\mathrm{Kg} \mathrm{m}^{-3}\right)$ & $755.22^{\mathrm{c}}$ & $877.23^{\mathrm{a}}$ & $782.21^{\mathrm{ab}}$ & $772.70^{\mathrm{a}}$ & $811.82^{\mathrm{a}}$ & $830.11^{\mathrm{a}}$ \\
a-Cellulose (\%) & $75.68^{\mathrm{a}}$ & $67.07^{\mathrm{b}}$ & $67.62^{\mathrm{b}}$ & $68.38^{\mathrm{a}}$ & $70.81^{\mathrm{a}}$ & $71.18^{\mathrm{a}}$ \\
Klason lignin (\%) & $45.90^{\mathrm{a}}$ & $36.40^{\mathrm{ab}}$ & $29.24^{\mathrm{b}}$ & $33.83^{\mathrm{a}}$ & $38.63^{\mathrm{a}}$ & $39.07^{\mathrm{a}}$ \\
Cold water solubility (\%) & $5.21^{\mathrm{a}}$ & $3.83^{\mathrm{a}}$ & $4.27^{\mathrm{a}}$ & $3.22^{\mathrm{a}}$ & $4.16^{\mathrm{a}}$ & $5.94^{\mathrm{a}}$ \\
Hot water solubility (\%) & $9.03^{\mathrm{a}}$ & $9.28^{\mathrm{a}}$ & $7.89^{\mathrm{a}}$ & $8.95^{\mathrm{a}}$ & $8.94^{\mathrm{a}}$ & $8.30^{\mathrm{a}}$ \\
$1 \%$ NaOH solubility (\%) & $41.35^{\mathrm{a}}$ & $42.76^{\mathrm{a}}$ & $40.97^{\mathrm{a}}$ & $42.16^{\mathrm{a}}$ & $39.27^{\mathrm{a}}$ & $43.65^{\mathrm{a}}$ \\
Alcohol-benzene solubility (\%) & $5.30^{\mathrm{a}}$ & $5.47^{\mathrm{a}}$ & $5.90^{\mathrm{a}}$ & $5.17^{\mathrm{a}}$ & $5.05^{\mathrm{a}}$ & $6.45^{\mathrm{a}}$ \\
\hline
\end{tabular}

Means with the same letter along the same row are not significantly different at $p \geq 0.05$

of bamboo was highly resistant. Termites and beetles were able to invade the bamboo from the cut end portion and through the inner layer, rather than directly through the exterior surface. This observation was similar to that of Mishra and Rana (1992), Mishra and Thakur (1998) and Nirmala and Kenneth (2011). The reason for this pattern of attack may be that the outer layer of bamboo has a considerable amount of ash and silica, and that these compounds help in improving natural durability as well as in imparting strength to bamboos (Nirmala and Kenneth 2011).

Resistivity of bamboo to powder-post was similar for all the age classes. As for resistance against termite, age 2 and 3 had similar resistivity while age 4 differed significantly (Table 6). Generally, age 4 had the highest resistance to termites, while age 3 had the highest resistance to powder-post beetle infestation. The reason for age 4 having the highest termite resistivity may be due to maturity of this age class. This findings correspond to the conclusion of Mishra and Thakur (1998) who reported that characteristics of bamboo such as age, diameter, height, felling season, seasoning method, etc. may have an effect on termite attack.

Along the culm length, there were no significant difference in termite resistivity (Table 6). The termites consumed the different portion of the bamboo the same way as powderpost beetle, which infested heavily on the basal portion of the culm while middle and top portion showed similar resistivity (Table 6 ). The reason for the significant variation in powder-post beetle attack along the culm may be due to that fact that the top portion of the culm is more dense, and thus, the insect infested the basal portion which is less dense (Sadiku, 2016). Considering the culm age, powder-post beetles attack were indifferent to the ages. Bamboo from all the ages were consumed the same way (Table 6).

\section{Influence of culm density and chemical properties on resistance to termite and powder-post beetles}

The relationship of $B$. vulgaris resistance with culm density and chemical properties are shown in Table 7. Age and portion of the culm from

Table $5 \quad$ F-values and level of significance from analysis of variance

\begin{tabular}{lllll}
\hline \multirow{3}{*}{ Termites } & Sourvce of variation & df & F-value & Significance \\
& Age & 2 & 5.428 & $0.014 * *$ \\
& Portion & 2 & 2.297 & $0.129 \mathrm{~ns}$ \\
\multirow{3}{*}{ Powder-post beetle } & Age*Portion & 4 & 0.523 & $0.720 \mathrm{~ns}$ \\
& Age & 2 & 0.81 & $0.456 \mathrm{~ns}$ \\
& Portion & 2 & 5.233 & $0.016 * *$ \\
& Age*Portion & 4 & 0.489 & $0.744 \mathrm{~ns}$ \\
\hline
\end{tabular}

** = Highly significant difference, $\mathrm{ns}=$ no significant difference 
Table 6 Results of Duncan Multiple Range Test (DMRT)

\begin{tabular}{lccc}
\hline Source of variation & Levels & Termites & Powder-post beetle \\
\hline \multirow{2}{*}{ Age (years) } & 2 & $48.31^{\mathrm{a}}$ & $10.25^{\mathrm{a}}$ \\
& 3 & $41.07^{\mathrm{a}}$ & $14.54^{\mathrm{a}}$ \\
& 4 & $17.81^{\mathrm{b}}$ & $13.04^{\mathrm{a}}$ \\
\multirow{3}{*}{ Portion } & Base & $27.71^{\mathrm{a}}$ & $18.93^{\mathrm{a}}$ \\
& Middle & $32.03^{\mathrm{a}}$ & $9.17^{\mathrm{b}}$ \\
& Top & $47.44^{\mathrm{a}}$ & $9.73^{\mathrm{b}}$ \\
\hline
\end{tabular}

Each value is the mean of 10 replicates; numbers within a column followed by the same letter are not significantly different (DMRT test, $\alpha=0.05$ )

which samples were cut showed significant negative correlation with termite $(-0.529)$ and powder-post $(-0.479)$ resistivity (Table 7$)$. This indicated that as bamboo ages, the weight loss to termite infestation decreases. Likewise, as one move from the base to the top, the weight loss to powder-post beetle attack decreases. Generally, no significant correlation existed between Bamboo's natural resistivity with culm density and chemical properties, in contrast to what were reported in literature (Table 7).

The relationship of chemical content with termite and powder-post beetle infestation showed that the extractive, cellulose and lignin content of bamboo showed influence on the rate of degradation, similar to the findings of Shanbag and Sundararaj (2013). The higher the cellulose content of the bamboo, the less resistance to termite attack (Table 10). The findings are similar to that of La Fage and Nutting (1978). However, the findings of this study showed that the higher the lignin content of the bamboo, the less resistant to termite attack, contrary to general opinion that bamboo is more resistant to termite attack compared to wood (Syafii et al. 1988). The pattern of consumption by termites and powder-post beetles may be due to higher quantity of starch which makes bamboo more susceptible to insect attack, as well as the bamboo's extractive and lignin components which may not be toxic enough to prevent the consumption of bamboo by termites (Grace et al. 1988, Sulthoni 1988, Grace 1987).

Findings from a previous study showed that density influences the termite's ability to fragment wood mechanically with its mandibles (Owoyemi et al. 2014). However, in this study, there were poor or weak correlation $\left(\mathrm{R}^{2}=\right.$ 0.109 and 0.366 ) between density and wood consumption by termite and powder-post beetle, respectively. Thus, increase in culm density does not ensure that bamboo consumption will decrease. Roszaini et al. (2017) and Peralta et

Table 7 Correlation of resistance with culm age, portion, density and chemical properties

\begin{tabular}{lcc}
\hline Properties & Termites & $\begin{array}{l}\text { Powder-post } \\
\text { beetle }\end{array}$ \\
\hline Age & $-0.529 * *$ & 0.145 \\
Culm portion & 0.342 & $-0.479^{*}$ \\
Culm density & 0.109 & 0.366 \\
Cellulose & 0.222 & -0.249 \\
Lignin & 0.371 & -0.127 \\
Cold water solubility & 0.176 & -0.174 \\
Hot water solubility & 0.148 & 0.042 \\
NaOH solubility & -0.041 & 0.184 \\
Alcohol-benzene solubility & -0.103 & -0.259 \\
\hline
\end{tabular}

$* *$ Correlation is significant at $0.01, *$ correlation is significant at 0.05 
al. (2004) worked on wood species, and did not find a strong correlation between wood density and termite resistance of different wood species. Thus, the use of density factor alone is not sufficient to determine the durability of either bamboo or timber (Roszaini et al. 2017). Therefore, density alone cannot confer durability to bamboo, similarly as timber.

\section{Resistance classification of Bambusa vulgaris}

Mean visual ratings of termite damage ranged from 9-4, 'slight attack' up to $3 \%$ of cross sectional area affected, to 'very severe attack', $50-70 \%$ of cross sectional area affected, for all ages and culm portion. While mean visual rating for powder-post beetle attack was 4 , 'very severe attack', 50-70\% of cross sectional area affected all through. The overall mass losses from termite infestation ranged from $17.81-48.31 \%$, while that of powder-post beetle was between 9.17-18.93\%.

Maximum termite damage was observed in age 2 and the top portion of the culm, while age 3 and basal portion of the culm were heavily infested by powder-post beetles (Table 6). The minimum attack by both termite and powder-post beetles were observed for the basal portion of age 4 and middle portion of age 2 , respectively. Weight loss to termite infestation of $B$. vulgaris was compared with heartwood of some Nigerian timber species; B. vulgaris from all ages and culm portion were naturally more durable than Linnea welwitchii (100\%), Irvingia gabonensis (94.59\%), Vernonia colorata $(67.05 \%)$ and Syzygium guineense $(63.03 \%)$.

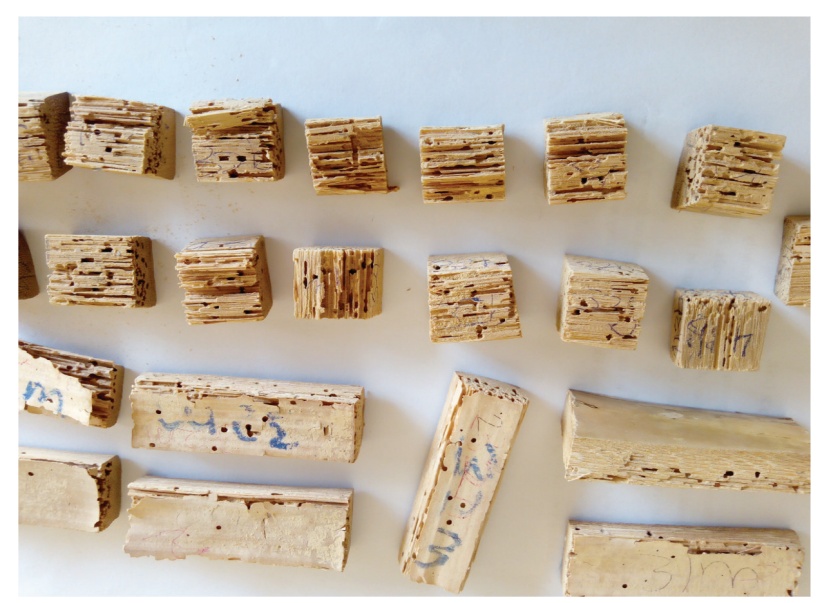

Figure 1 Bamboo test blocks showing damage from powder-post beetle attack

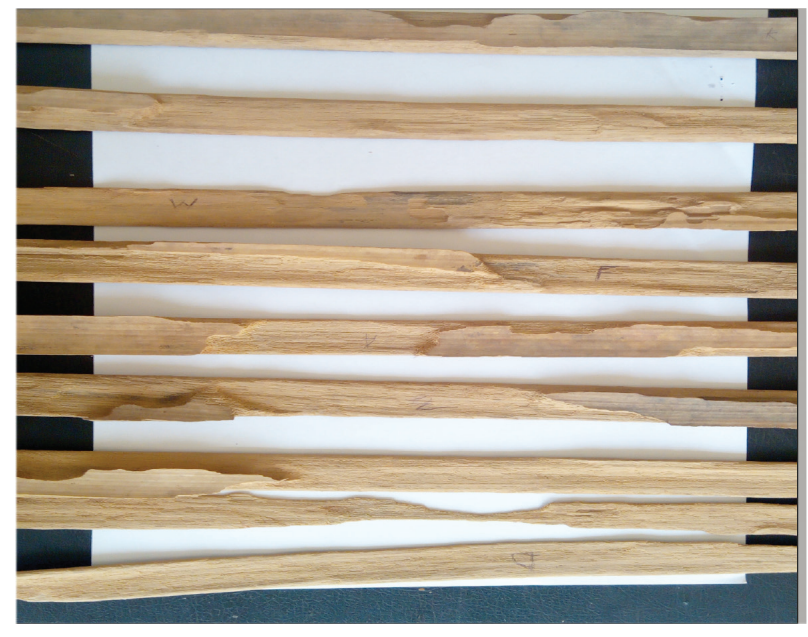

Figure 2 Bamboo test samples showing damage from Subterranean termite attack

According to the durability classification developed by SNI 01.7207-2006, based on the percentage weight loss to termite and powder-post infestation, $B$. vulgaris from the three age classes were grouped into resistance class. Bamboo from age 2 were grouped as 'non resistant', age 3 'moderately resistant', and age 4 'resistant'. The basal and middle portion were also classified as 'moderately resistant', while the top portion was perishable (Table 8). The findings of this study was similar to that of Febrianto et al. (2014), who grouped resistance of $B$. vulgaris against Coptotermes curvignathus (subterranean termites) as belonging to class IV (poor). It was also reported that the resistance of $B$. vulgaris against Anobium spp. were lower compared to those of Gigantochloa apus, Gigantochloa atroviolaceae and Dendrocalum asper. Nirmala and Kenneth (2011) reported similar findings. The resistant classification of B. vulgaris in its natural form is in accordance to the findings of Mishra and Rana (1992) who concluded that bamboos are perishable timbers and are generally not resistant to degradation.

\section{CONCLUSIONS}

The findings of this study showed that age had significant influence on termite resistivity of $B$. vulgaris, while resistance to powder-post beetle infestation depended on the portion of the culm. The higher the cellulose content, the less resistance to termite infestation. However, the higher the lignin content, the less resistance the bamboo was to termite attack. There were 
Table 8 Weight loss, visual rating and resistance classification according to SNI 01.7207-2006 and AWPA Standard E1-09 (2009)

\begin{tabular}{|c|c|c|c|c|c|c|}
\hline \multirow[t]{2}{*}{ Levels } & \multicolumn{3}{|c|}{ Termites } & \multicolumn{3}{|c|}{ Powder-post beetles } \\
\hline & $\begin{array}{c}\text { Weight loss } \\
(\%)\end{array}$ & $\begin{array}{l}\text { Visual } \\
\text { rating }\end{array}$ & $\begin{array}{l}\text { Class of } \\
\text { resistance }\end{array}$ & $\begin{array}{c}\text { Weight loss } \\
(\%)\end{array}$ & $\begin{array}{l}\text { Visual } \\
\text { rating }\end{array}$ & $\begin{array}{l}\text { Class of } \\
\text { resistance }\end{array}$ \\
\hline 2 years & 48.31 & 4 & Non-resistant & 10.25 & 4 & Poor \\
\hline 3 years & 41.07 & 8 & Moderately resistant & 14.54 & 4 & Poor \\
\hline 4 years & 17.81 & 9 & Resistant & 13.04 & 4 & Poor \\
\hline Base & 27.71 & 8 & Moderately resistant & 18.93 & 4 & Poor \\
\hline Middle & 32.03 & 8 & Moderately resistant & 9.17 & 4 & Poor \\
\hline Top & 47.44 & 4 & Non-resistant & 9.73 & 4 & Poor \\
\hline
\end{tabular}

weak correlation between density and chemical content for wood consumption by termite and powder-post beetle respectively. Bamboo from age 4 were resistance to termites, while for age 3 , the basal and middle portion were grouped into 'moderately resistant' class. The resistance of B. vulgaris, from all age classes and culm portions, against powder-post beetle infestation was poor, and therefore placed in class IV. Bambusa vulgaris resistivity to termite and powder-post beetle attack had a significant negative correlation with age and culm portion respectively. The findings of this study showed that B. vulgaris is not highly resistant to termite attack and powderpost beetles, and therefore need preservative or modification treatment to confer a reasonable level of protection against biological agents of degradation.

\section{ACKNOWLEDGEMENT}

This study was financially supported by a research grant from the 2015 Institution Based Tertiary Education Trust Fund (TETFUND), Nigeria.

\section{REFERENGES}

AbD-LatiF M, Khoo KC \& Nor Azah MA. 1991. Carbohydrates in some natural stand bamboos. Journal TropicalForest Science 4: 310-316.

Aminudin S, Rudi D, Nuruddin N et al. 2018. Review on quality enhancement of bamboo utilization: preservation, modification and applications. A review. Asian Journal of Plant Sciences 17: 1-18.

ASTM (American Society For Testing and Materials) 1993. ASTM D 2395-93 (reapproved 1997): Standard Test Methods for Specific Gravity of Wood and Wood-Based Materials. Annual Book of ASTM Standards, Section 4. Volume 04.10: Woods. ASTM, West Conshohocken.

AWPA (American Wood Preservers' Association) E1-09. 2009. Standard Method for Laboratory Evaluation to Determine
Resistance to Subterranean Termites. American Wood Preservers' Association, Woodstock.

AWPA (American Wood Preservers' Association) 2006. Standard Test Method for Evaluation of Preservative Treatments for Lumber and Timber Against Subterranean Termites in Above Ground, Protected Applications (UC1 Eे UC2) Standard E21-06. AWPA Annual Book of Standards. AWPA, Birmingham.

Chauhan L, Dhawan S \& Gupta S. 2000. Effect of age on anatomical and physico-mechanical properties of three Indian bamboo species. Journal of the T.D.A. 46: 11-17.

Chavan Ma \& Attar AC. 2013. Study feasibility of preservative chemicals and its effect on load carrying capacity of bamboo. International Journal of Scientific and Engineering Research 4: 1271-1278.

DAS M \& Chakraborty D. 2006. Influence of alkali treatment on the fine structure and morphology of bamboo fibres. Journal of Applied Polymer Science 102: 50505056.

DhaWAN S \& Mishra SC. 2005. Influence of felling season and moon phase on natural resistance of bamboos against termite. Indian Foresters 131: 1486-1492.

Febrianto F, Gumilang A, Maulana S, Busyra I \& Purwaningsih A. 2014. Natural durability of five bamboo species against termites and powder post beetle. Jurnal Ilmu dan Teknologi Kayu Tropis 12: 2.

Grace JK, Wong AHH \& Tome CHM. 1998. Termite Resistance of Malaysian and Exotic Woods With Plantation Potential: Laboratory Evaluation. The International Research Group on Wood Preservation, Stockholm.

GraCE JC. 1987. The challenge of wood destroying insects. Proceeding of the Canadian Wood Preservation Association 7: 3-12.

Huang XY, Xie JL, Qi JQ, Hao JF, Jiang XQ \& Hu WH. 2014. Investigation of the physical and mechanical properties and chemical composition of Bambusa rigida before and after accelerated aging. BioResources 9: 3174-3184.

SNI (Indonesia National Standard) 2006. Wood and Wood Products Resistance Test To Wood Destroying Organism (SNI 01.7207-2006). Indonesian National Standard Bureau, Jakarta.

Kim JJ, Lee SS, Ra JB, Lee H, Huh N \& Kim GG. 2011. Fungi associated with bamboo and their decay capabilities. Holzforschung, 65: 271-275. 
Kumar S, Shukla KS, Dev I \& Dobriyal PB. 1994. Bamboo Preservation Techniques: A Review. Technical Report No. 3. International Network for Bamboo and Rattan (INBAR), New Delhi, and Indian Council of Forestry Research and Education (ICFRE), Dehra Dun.

LA FAGE JP \& Nutting WL. 1978. Nutrient dynamics of termites. Pp 41 in Brian MV (ed) Production Ecology of Ants And Termites. Cambridge University Press, London.

Mishra SC \& RANA SS. 1992. Laboratory evaluation of natural resistance of bamboos to termite Microcerotermes beesoni Snyder (Isoptera: Termitidae). Journal of Entomological Research Society 16: 311-318.

Mishra SC \& Thakur ML. 1998. Laboratory evaluation of natural resistance of bamboos to termites. Indian Foresters 124: 1043-1046.

Nielsen KF, Holm G, Uttrup LP \& Nielsen PA. 2004. Mould growth on building materials under low water activities. Influence of humidity and temperature on fungal growth and secondary metabolism. International Biodeterioration $\mathcal{E}$ Biodegradation 54 : 325-336.

Nirmala KH \& Kenneth JG. 2011. Comparative study of the resistance of six Hawaii-grown bamboo species to attack by the subterranean termites Coptotermes formosanus Shiraki and Coptotermes gestroi (Wasmann) (Blattodea: Rhinotermitidae). Insects 2 475-485. doi:10.3390/insects2040475.

Ogunsanwo OY \& Terziev N. 2010. Mechanical properties of glue-laminated boards of bamboo Bambusa vulgaris from Nigeria. Pp 183-186 in Kudela J \& Lagava R (eds) Proceedings of $6^{\text {th }}$ International Symposium on Wood Structure and Properties, Arbora Publishers, Zvolen.

Ogunsanwo OY, Terziev N, Panov D \& Daniel G. 2015. Bamboo (Bambusa vulgaris Shrad.) from Moist Forest and Derived Savanna Locations in South West Nigeria - Properties and Gluability. BioResources 10: 2823-2835.

Olajide OB, Ogunsanwo O \& Aina KS. 2013. Strength properties of thermal treated glue lam of bamboo Bambusa vulgaris (Schrad Ex J.C.Wendl) International Journal of Advanced Biological Research 3: 281-288.

Owoyemi JM, Olaniran OS \& Aliyu DI. 2014. Effect of density on the natural resistance of ten selected Nigerian wood species to subterranean termites. Pro Ligno 9: 3-11.

Pasanen AL, Kasanen JP, Sirpa R, Ikaheimo M, Rantamaki J, KaAriainen H \& Kalliokoski P. 2000. Fungal growth and survival in building materials under fluctuating moisture and temperature. International Biodeterioration $\mathcal{E}$ Biodegradation. 46: 117-127.

Peralta RCG, Menezes EB, Carvlho AG \& Aguiar-Menezes EL. 2004. Wood consumption rate of forest by subterranean termites (Isoptera) under field conditions. Revista Arvore 28: 1-7.

Razak W, Tamizi M, Othman S, Aminuddin M, AfFendy H \& IZYAN K. 2010. Anatomical and physical properties of cultivated two and four-year-old Bambusa vulgaris. Sains Malaysiana 39: 571-579.

Roszaini K, Salmiah U, Rahim S et al. 2017. Qualitative and Quantitative Determination of Resistance of
Twenty Two Malaysian Commercial Timbers through Subterranean Termite Feeding Behavior. Forest Research and Engineering International Journal 1: 1-11.

Sadiku NA, Oluyege AO \& AJayI B. 2016. 2 Fibre dimension and chemical characterisation of naturally grown Bambusa vulgaris for pulp and paper production. Journal of Bamboo and Rattan 15: 33-43.

SADIKU NA \& BADA SO. 2017. Technical rotation age for naturally-grown Bambusa vulgaris for fibre, fuel and structural application. Journal of Tropical Forest Science. 29: 541-548.

Schmidt O, Wei DS, Liese W \& Wollenberg E. 2011. Fungal degradation of bamboo samples. Holzforschung 65: 883-888.

Shanbag RR \& Sundararaj R. 2013. Imported wood decomposition by termites in different agro-eco zones of India. International Biodeterioration and Biodegradation 85: 16-22.

Sulthoni A. 1988. A simple and cheap method of bamboo preservation. Pp 209-211 in Ramanuja IV et al. (eds) Proceeding of the $3^{\text {rd }}$ International Bamboo Workshop. Kerala Forest Reserch Institute, Kerala.

Suprapti S. 2010. Decay resistance of five Indonesian bamboo species against fungi. Journal Tropical Forest Science 22: 287-294.

Syafi W, Samejima M \& Yoshimoto T. 1988. The role of extractives in decay resistance Ulin wood (Eusideroxylon zwageri T. Et. B.). Bulletin of Tokyo University and Forestry 77: 1.

TAPPI (Technical Association of the Pulp and Paper Industry) 1997. Solvent Extractives of Wood and Pulp. T204 cm. TAPPI, Atlanta. USA.

tappi (Technical Association of the Pulp and Paper Industry) 2006. Acid-Insoluble Lignin in Wood And Pulp. T222 cm. TAPPI, Atlanta.

TAPPI (Technical Association of the Pulp and Paper INDUSTRY) 1985. Carbohydrate Composition of ExtractiveFree Wood and Wood Pulp by Gas-Liquid Chromatography. TAPPI Method T249 cm-85. TAPPI, Atlanta.

TAPPI (Technical Association of the Pulp and Paper Industry) 1999. Water Solubility of Wood and Pulp. T207 cm. TAPPI, Atlanta.

TAPPI (Technical Association of the Pulp and Paper Industry) 2002. One Percent Sodium Hydroxide Solubility of Wood and Pulp. T212cm. TAPPI, Atlanta.

TAPPI (Technical Association of the Pulp and Paper Industry). 1999. Alpha-, beta- and gamma-cellulose in pulp. T203 cm-99. TAPPI Standard Test Method. TAPPI, Atlanta.

Thapa RS, Singh P \& Bhandari RS. 1992. Prophylactic efficacy of various insecticides for the protection of bamboos in storage against ghoon borers, Dinoderus spp. Part 8. Journal of the Indian Academy of Wood Science 23: 39-44.

Wei D, Schmidt O \& Liese W. 2013. Durability test of bamboo against fungi according to EN standards. European Journal of Wood and Wood Products 71: 551-556.

Xu G, Wang L, Liu J \& Hu S. 2013. Decay resistance and thermal stability of bamboo preservatives prepared using camphor leaf extract. International Biodeterioration and Biodegradation 78: 103-107. 